JMI Vol. 42 No. 2, Desember 2020

METAL INDONESIA

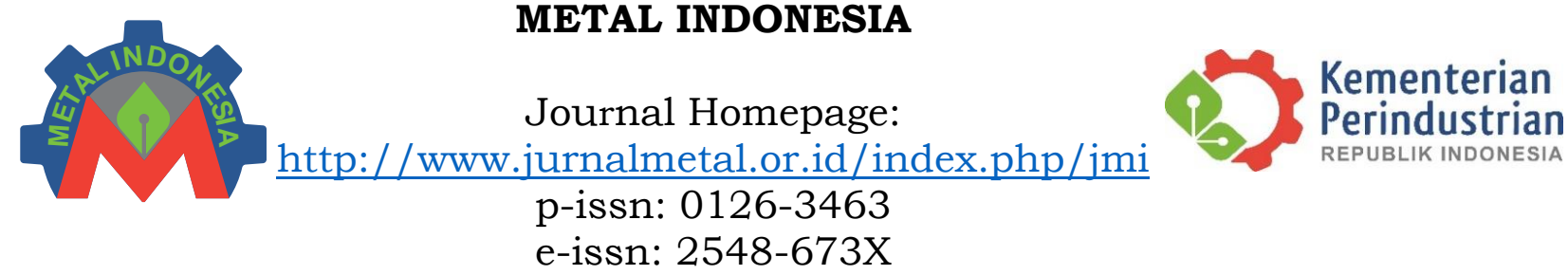

\title{
PENGARUH VARIASI HOLDING TIME DAN MEDIA PENDINGIN PADA PROSES SOLUTION TREATMENT TERHADAP KEKERASAN DAN KETANGGUHAN PADUAN BAJA Fe12Mn1,5Mo
}

\begin{abstract}
EFFECT OF HOLDING TIME AND QUENCHANT VARIATION ON HARDNESS AND IMPACT PROPERTIES OF Fe12Mn1.5MO STEEL BY SOLUTION TREATMENT PROCESS
\end{abstract}

\author{
Faried Miftahur Ridlo', Permana Andi Paristiawan', Mukhlis Agung Prasetyo \\ ${ }^{1}$ Pusat Penelitian Metalurgi dan Material, Lembaga Ilmu Pengetahuan Indonesia, \\ Kawasan Puspiptek, Serpong, Tangerang Selatan, Indonesia \\ E-mail : fari007@lipi.go.id
}

\begin{abstract}
Abstrak
Baja mangan austenitik merupakan baja yang digunakan secara luas pada industri tambang dan mineral karena memiliki ketahanan aus dan ketangguhan yang tinggi. Secara umum, baja mangan austenitik yang dibuat melalui proses pengecoran memiliki kecenderungan getas dengan ketangguhan yang rendah karena terbentuknya formasi karbida. Proses solution treatment diikuti dengan pendinginan cepat menjadi hal penting untuk melarutkan karbida sehingga menjamin terbentuknya struktur full austenit pada temperatur kamar. Penelitian ini bertujuan untuk mengetahui pengaruh variasi holding time dan media pendingin pada proses solution treatment terhadap kekerasan dan ketangguhan paduan baja Fe12Mn1.5Mo. Pada penelitian ini, karakteristik baja Fe12Mn1.5Mo hasil cor diinvestigasi lebih lanjut setelah dilakukan proses solution treatment dalam dua tahap, yaitu memanaskan dari temperatur ruang sampai $700^{\circ} \mathrm{C}$ dengan holding time $3 \mathrm{jam}$, kemudian dinaikkan sampai temperatur $1000^{\circ} \mathrm{C}$ dengan variasi holding time selama 1 jam, 2 jam dan 3 jam diikuti dengan quenching menggunakan 3 media pendingin berbeda (air, larutan garam $1.5 \%$ dan 3\%). Pada pendinginan menggunakan larutan garam $1.5 \%$ dan $3 \%$ menunjukkan bahwa semakin lama holding time, maka nilai kekerasan dan nilai impak juga semakin meningkat. Sementara itu, spesimen yang didinginkan menggunakan air menghasilkan nilai yang berfluktuasi untuk kedua sifat mekanik. Nilai kekerasan tertinggi sebesar 344 BHN pada variasi holding time 2 jam diikuti dengan pendinginan air, sementara nilai impak tertinggi sebesar $73.7 \mathrm{~J} / \mathrm{cm}^{2}$ dihasilkan pada variasi holding time 1 jam dengan pendinginan air. Nilai impak terendah sebesar $48.8 \mathrm{~J} / \mathrm{cm}^{2}$ dihasilkan pada variasi holding time 1 jam dengan pendinginan larutan garam 3\%. Hasil metalografi menunjukkan bahwa struktur mikro matriks austenit yang mengakibatkan nilai kekerasan yang rendah sedangkan karbida tak terlarut yang terdispersi di batas butir dan di dalam butir yang mengakibatkan nilai kekerasan yang tinggi. Di sisi lain, Proses solution treatment yang berlangsung kurang sempurna berakibat pada menurunnya ketangguhan karena terbentuknya presipitasi karbida.
\end{abstract}

Kata Kunci: baja mangan austenitik, proses solution treatment, media pendingin 


\begin{abstract}
The austenitic manganese steel is extensively used for applications in the mineral and mining industries due to high wear resistance and high toughness.. In general, austentic manganese steel made by casting process has a tendency to be brittle with low toughness due to the formation of carbide. The solution treatment followed by rapid cooling is essential to ensure the formation of full austenitic structure at room temperature by dissolving the carbides This experiment focused on the effect of holding time and quenchant variation on hardness and impact properties of Fe12Mn1.5Mo by solution treatment process. In this study, the characteristics of modified cast Fe12Mn1.5Mo steel were investigated further after subjected to solution treatment process in two stages heating starts at room temperature to $700 \mathrm{oC}$ for 3 hours holding time, then raised at temperature to $1000 \mathrm{oC}$ with solutionizing time variations for 1 hour, 2 hours and 3 hours followed by rapid cooling using 3 different quenchants (water, $1.5 \%$ and $3 \%$ salt solution). Solution treatment followed by $1.5 \%$ and $3 \%$ salt solution cooling has produced higher hardness and impact value with increasing of holding time. Meanwhile, specimen that experienced water quenching give the fluctuated value for both of properties. The highest hardness was resulted at 2 hours holding time followed by water quenching which reached $344 \mathrm{BHN}$ and the highest impact value of $73.7 \mathrm{~J} / \mathrm{cm} 2$ resulted at 1 hour holding time with similar water quenching. However, minimum absorbed energy of $48.8 \mathrm{~J} / \mathrm{cm} 2$ occured at 1 hour holding time followed by $3 \%$ salt solution cooling. Final microstructure showed that austenite matrix give effect on low hardness, whereas undissolved carbide which dispersed along grain boundaries and within the grains result in high hardness. On the other hand, the incomplete solution treatment processing affected on decreasing of toughness due to the formation of carbide precipitation.
\end{abstract}

Keywords : austenitic manganese steel, solution treatment, quenchants

\section{PENDAHULUAN}

Baja Mangan yang dikenal dengan "Hadfield steel" pertama kali ditemukan oleh Sir Robert Hadfield pada tahun 1882 mengandung 1 $1.4 \%$ karbon dan unsur Mangan 11 - $14 \%$ untuk aplikasi ketahanan aus tinggi (Agunsoye and Talabi 2015) (Nurjaman, et al. 2017). Karakteristik dari baja Mangan yang memiliki sifat kekerasan, ketangguhan serta ketahanan aus yang tinggi (Winarto, et al. 2019) sangat cocok diaplikasikan pada kondisi beban dinamis, khususnya pada industri yang membutuhkan performa tinggi seperti industri pemrosesan mineral dan tambang (crusher, lining plates, jaws, hammers) serta industri energi (Tecza and Sobula 2014).

Secara umum, baja mangan dibuat melalui proses pengecoran yang menghasilkan fasa full austenite dengan keberadaan karbida $(\mathrm{FeMn})_{3} \mathrm{C}$ pada batas butir,sehingga cenderung memicu penggetasan (Hidayat and Bandanadjaja 2018). Sifat mekanik yang optimal pada baja Mangan diperoleh melalui proses perlakuan panas, dimana solution treatment yang diikuti dengan pendinginan cepat merupakan proses perlakuan panas yang umum dilakukan untuk menghilangkan penggetasan akibat karbida di batas butir (baik berupa intergranular carbide maupun acicular carbide) (Pratomo, et al. 2016), sehingga diperoleh struktur austenitik yang homogen setelah proses pengecoran (Ham, et al. 2010). Secara umum, solution treatment meliputi proses austenisasi pada temperatur berkisar 1000 ${ }^{\circ} \mathrm{C}-1100{ }^{\circ} \mathrm{C}$, kemudian ditahan selama waktu tertentu dan didinginkan cepat ke dalam media air (Okechukwu, et al. 2017). Elaborasi siklus perlakuan panas pada baja Mangan sangat penting untuk mengetahui optimasi distribusi dan bentuk karbida pada baja Mangan austenitik (Nurjaman, et al. 2017). Keberadaan fasa austenit menyebabkan baja Mangan memiliki karakteristik koefisien thermal ekspansi besar (Kumar 2019) yang mengakibatkan thermal shock ketika baja Mangan dipanaskan secara cepat, sehingga metode pemanasan bertahap (step heating) lebih tepat digunakan (Banerjee 2017).

Beberapa peneliti melakukan elaborasi proses perlakuan panas untuk mengoptimalkan distribusi dan bentuk karbida pada baja mangan dengan memvariasikan media pendingin untuk mendapatkan laju pendinginan yang berbeda (Hosseini and Limooei 2011). Dalam eksperimennya, S.Hosseini, dkk menggunakan larutan garam untuk meningkatkan laju pendinginan, sehingga mampu menurunkan volum karbida. Selain itu, penambahan 
konsentrasi pada larutan garam dapat meningkatkan kekerasan baja Mangan karena matriks austenit mampu mempertahankan lebih banyak karbon sebagai karbon terlarut. Hasil senada didapatkan melalui penelitian sebelumnya (Ridlo, et al. 2020) yang melakukan studi awal pengaruh proses solution treatment terhadap struktur mikro dan kekerasan baja Mangan dengan variasi waktu tahan diikuti pendinginan cepat pada media pendingin air. Dari pengujian kekerasan, menunjukkan bahwa nilai kekerasan meningkat dengan bertambahnya waktu tahan. Bahfie, et.al. menyatakan bahwa peningkatan temperatur austenisasi mempengaruhi struktur mikro dan sifat mekanik pada baja Mangan, di mana peningkatan temperatur austenisasi mengakibatkan karbida larut ke dalam matriks austenit sehingga menurunkan kekerasan dan meningkatkan ketangguhan (Bahfie, et al. 2020).

Perilaku mekanik baja Mangan sangat dipengaruhi oleh komposisi kimia (Enginsoy, Bayraktar and Kursun 2018), perlakuan panas dan work hardening (Winarto, et al. 2019). Pada penelitian ini, melanjutkan studi awal yang dilakukan oleh penulis (Ridlo, et al. 2020). Penelitian ini ditujukan untuk mengetahui pengaruh proses solution treatment dengan variasi parameter waktu tahan (holding time) pada proses pelakuan panas baja Mangan dilanjutkan dengan pendinginan cepat menggunakan media pendingin yang berbeda terhadap struktur mikro dan sifat mekanik pada baja Mangan.

\section{METODOLOGI}

\section{Sampel}

Bahan yang digunakan dalam penelitian ini adalah baja mangan hasil proses pengecoran pada tanur induksi berkapasitas $100 \mathrm{Kg}$. Komposisi kimia akhir yang didapatkan melalui pengujian OES (Optical Emission Spectroscopy) SpectroLab seperti pada Tabel 1.

\section{Proses Solution Treatment}

Proses pemanasan dilakukan menggunakan metode step heating dalam 2 tahap, dimana tahap pertama dengan memanaskan spesimen dari temperatur kamar hingga temperatur $700^{\circ} \mathrm{C}$ dengan holding time selama $3 \mathrm{jam}$. Kemudian tahap kedua dilanjutkan pemanasan hingga mencapai temperatur $1000^{\circ} \mathrm{C}$ (holding temperature) dengan variasi holding time selama 1 jam, 2 jam dan 3 jam. Proses solution treatment dilakukan menggunakan tungku muffle Nabertherm seri LH-15/14"/C440 dilanjutkan dengan pendinginan cepat menggunakan media pendingin berbeda yang diagitasi (air, larutan garam 1.5\% dan larutan garam 3\%) dengan skema proses perlakuan panas ditunjukkan pada Gambar 1.

Tabel 1. Komposisi Paduan Fe12Mn1.5Mo

\begin{tabular}{cc}
\hline Unsur & Komposisi (\%) \\
\hline $\boldsymbol{C}$ & 1,51 \\
\hline $\boldsymbol{M n}$ & 12,05 \\
\hline $\boldsymbol{N i}$ & 0,03 \\
\hline $\boldsymbol{S i}$ & 0,95 \\
\hline $\boldsymbol{P}$ & 0,02 \\
\hline $\boldsymbol{M o}$ & 1,49 \\
\hline $\boldsymbol{S}$ & $\leq 0,002$ \\
\hline $\boldsymbol{F e}$ & Bal.
\end{tabular}

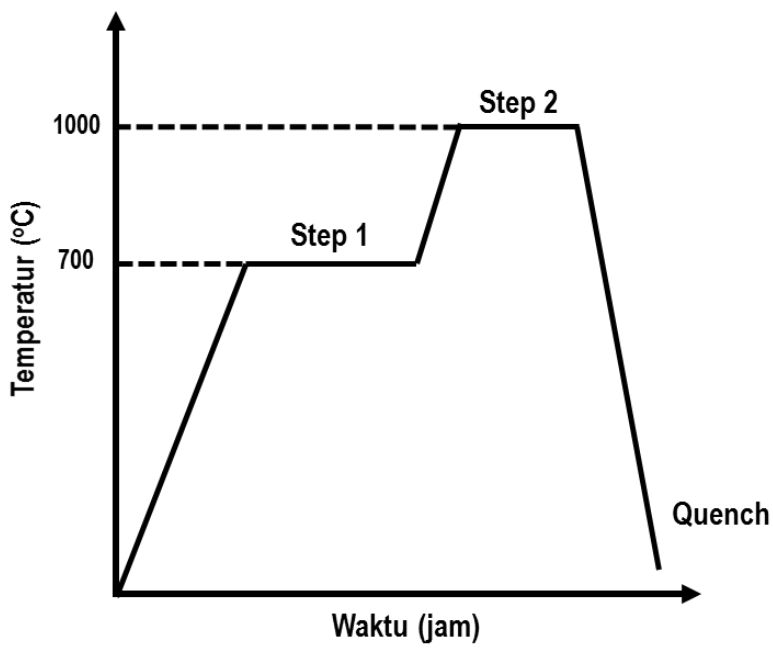

Gambar 1. Siklus pemanasan bertahap (Step Heating)

Sedangkan variasi holding time dan media pendingin ditunjukkan pada Gambar 2. 


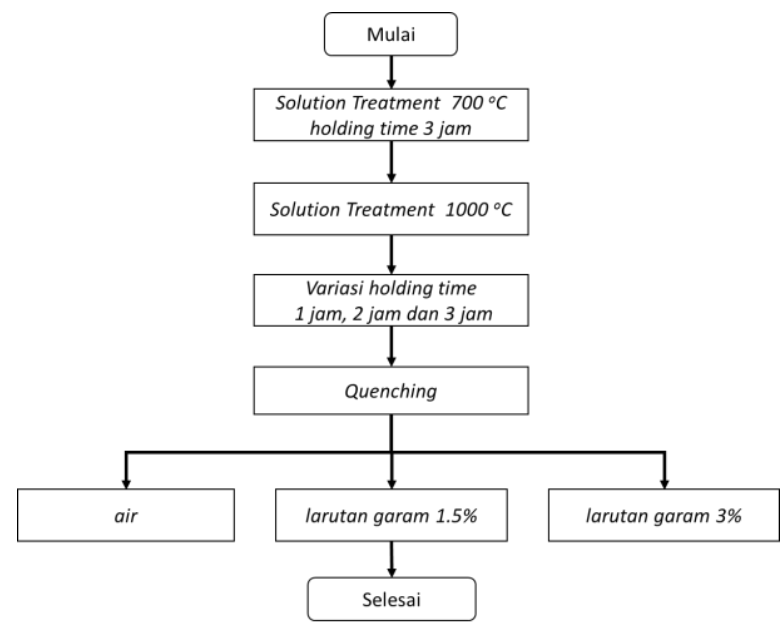

Gambar 2. Diagram alir variasi holding time dan variasi media pendingin

\section{Pengamatan Struktur Mikro}

Pengamatan struktur mikro pada sampel dilakukan menggunakan mikroskop optik Olympus BX53M dengan total perbesaran 500x. Untuk preparasi, sampel dipotong dengan dimensi $55 \times 7.5 \times 10 \mathrm{~mm}$ menggunakan mesin wirecut EDM untuk meminimalisir pengaruh panas pada perubahan sifat mekanik sebelum dilakukan proses solution treatment. Pengamatan struktur mikro menggunakan teknik metalografi diawali dengan melakukan proses amplas pada spesimen menggunakan kertas abrasif dengan kekasaran 80 $\mu \mathrm{m}, 120 \mu \mathrm{m}, 220 \mu \mathrm{m}, 600 \mu \mathrm{m}, 1000 \mu \mathrm{m}$ dan 1500 $\mu \mathrm{m}$ berturut-turut. Kemudian dilanjutkan dengan pemolesan menggunakan alumina $3 \mu \mathrm{m}$ dan $1 \mu \mathrm{m}$ sampai bekas goresan menghilang dan mengkilat. Selanjutnya, masing-masing spesimen dicelupkan ke dalam larutan etsa menggunakan larutan Nital $2 \%\left(2 \mathrm{~mL} \mathrm{HNO}_{3}+98 \mathrm{~mL}\right.$ ethanol) selama 5 - 10 detik. Spesimen yang telah dietsa dibersihkan menggunakan larutan alkohol dan dikeringkan menggunakan pengering.

\section{Pengujian Kekerasan dan Impak}

Pengujian kekerasan dilakukan menggunakan metode Brinell menggunakan mesin Affri Italy dengan indentor bola baja berdiameter $2.5 \mathrm{~mm}$; kemudian beban sebesar $187.5 \mathrm{Kg}$ dipenetrasikan selama kurang lebih 20 detik pada permukaan spesimen. Spesimen diuji dengan jumlah pengujian sebanyak 5 kali untuk masing-masing variasi perlakuan. Sementara itu, uji impak dilakukan sesuai standard ASTM E23 dengan metode Charpy impact test pada temperatur kamar dengan dimensi subsize sebesar $55 \times 7,5 \times 10 \mathrm{~mm}$.

\section{HASIL DAN PEMBAHASAN Analisis Pengaruh Holding Time Pada Variasi Media Pendingin Terhadap Mikrostruktur}

Struktur mikro baja mangan setelah proses solution treatment pada perbesaran $500 \mathrm{x}$ ditunjukkan pada Gambar 3. Berdasarkan diagram fasa Fe-Mn-C (Okamoto 1992), proses pemanasan pada baja dengan $12 \%$ Mangan pada $1000{ }^{\circ} \mathrm{C}$ akan menghasilkan fasa fully austenite, dimana laju pendinginan sangat berperan penting dalam pembentukan fasanya.

Dari hasil uji metalografi, proses solution treatment yang dilakukan menghasilkan struktur mikro austenit yang dominan, meskipun belum sepenuhnya membentuk struktur austenit yang penuh (purely austenitic structure). Secara umum terlihat struktur mikro berupa matriks austenit dengan karbida tak larut (undissolved carbide) yang terdispersi pada batas butir membentuk koloni tertentu dan juga terdapat sedikit di dalam butir, dimana karbida tak larut ditunjukkan oleh fasa berwarna putih. Pada proses solution treatment dengan variasi holding time 1 jam diikuti dengan pendinginan air, jumlah koloni karbida pada batas butir terlihat lebih banyak dibandingkan dengan variasi holding time 2 jam dan 3 jam. Hal ini mengindikasikan bahwa dengan semakin lama waktu tahan, karbida memiliki waktu yang cukup untuk larut dalam matriks austenit. Senada dengan hasil penelitian Bambang Widyanto,dkk yang menyatakan bahwa waktu yang diperlukan untuk disosiasi karbida ke dalam fasa austenit selama proses solution treatment telah tercapai. (Widyanto and Sambas 2007).

Sementara itu, pada pendinginan menggunakan larutan garam 1,5\%, terlihat struktur mikro berupa koloni karbida yang terdistribusi secara tidak homogen pada batas butir serta memiliki bentuk yang hampir serupa pada semua variasi waktu tahan. Hal serupa juga terlihat pada struktur mikro pada pendinginan larutan garam 3\%, meskipun pada waktu tahan 3 jam, batas butir tidak terlihat dengan jelas. 

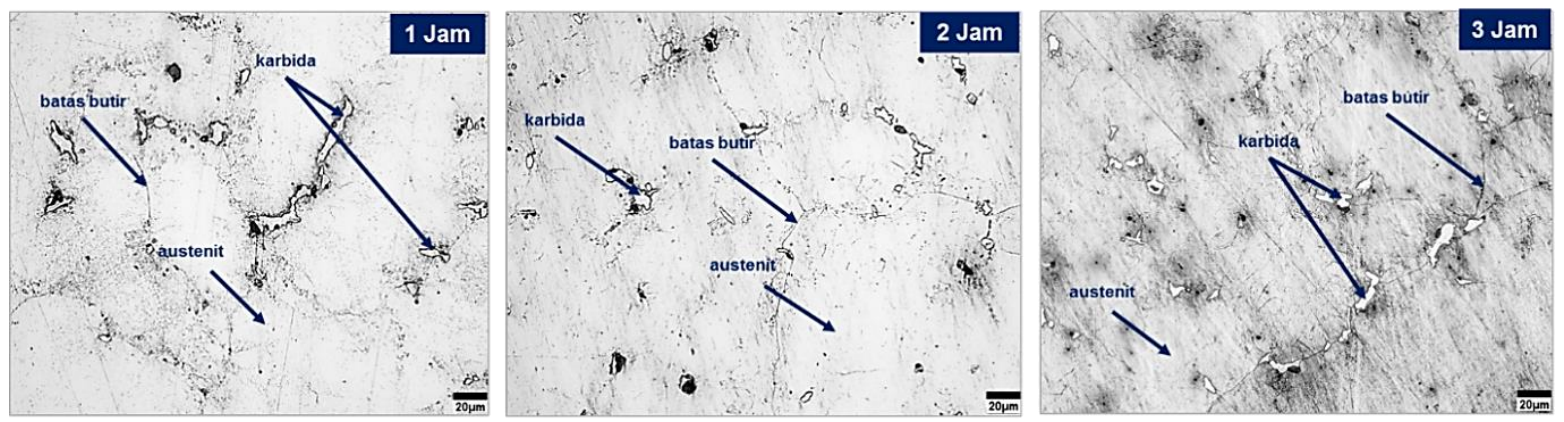

(a)
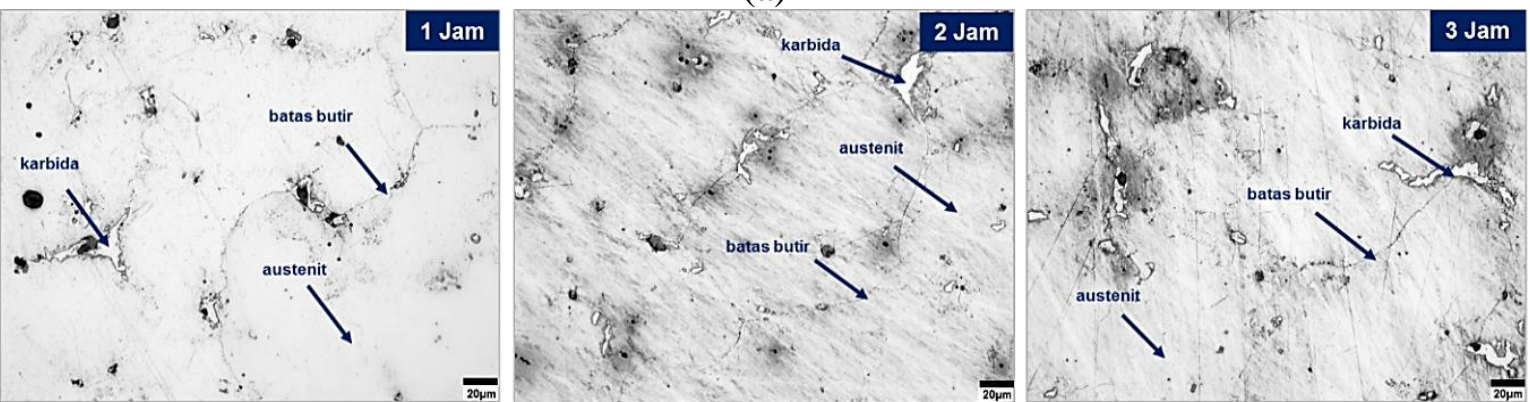

(b)
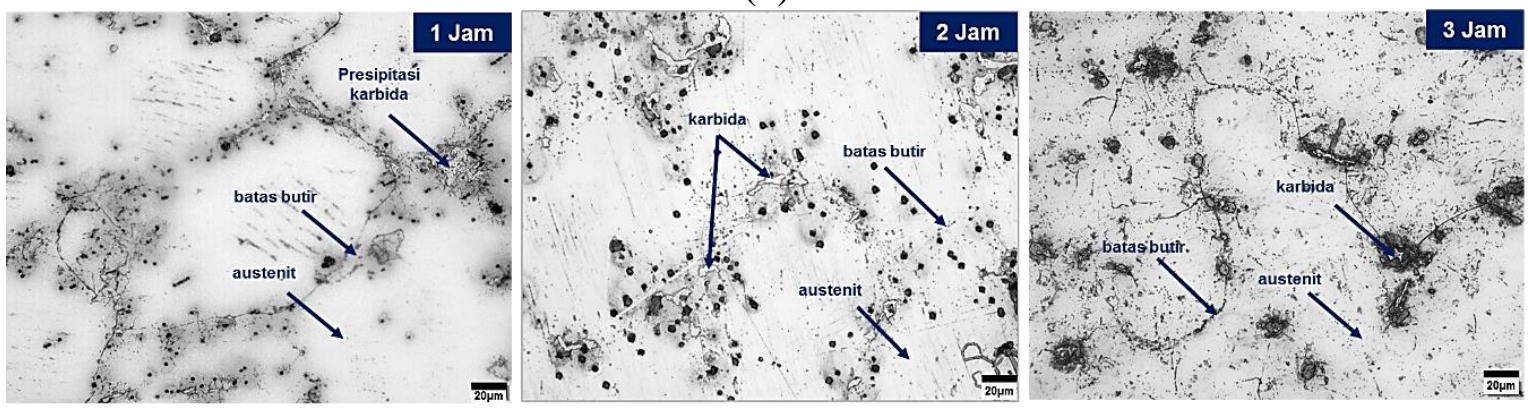

(c)

Gambar 3. Struktur mikro paduan Fe12Mn1,5Mo (as-treated) (a) pendinginan air, (b) pendinginan larutan garam $1,5 \%$, dan $(\mathrm{c})$ pendinginan larutan garam $3 \%$

\section{Analisis Pengaruh Waktu Tahan dan Variasi Media Pendingin Terhadap Kekerasan}

Pengaruh variasi waktu tahan dilanjutkan dengan pendinginan cepat menggunakan media pendingin yang berbeda terhadap nilai kekerasan ditunjukkan pada Gambar 4. Pada pendinginan menggunakan larutan garam $1.5 \%$, variasi holding time tidak memberikan pengaruh besar terhadap nilai kekerasan spesimen. Hal ini ditunjukkan dengan kecenderungan nilainya stabil, dengan rata-rata sebesar $233 \mathrm{BHN}$.

Sebaliknya, semakin lama holding time berpengaruh terhadap peningkatan kekerasan spesimen pada pendinginan menggunakan larutan garam 3\%, meskipun peningkatan yang terjadi tidak cukup signifikan yaitu sebesar 264 BHN,
276 BHN dan 278 BHN, berturut-turut. Sementara itu, pada spesimen dengan pendinginan air, menunjukkan nilai kekerasan yang berfluktuasi , dimana nilai kekerasan meningkat pada sampel dengan parameter holding time 2 jam, kemudian kembali menurun setelah 3 jam. Pada eksperimen ini, hal tersebut disebabkan karena perbedaan jumlah molibdenum sebagai unsur pembentuk karbida (Ridlo, et al. 2020). Nilai kekerasan paduan Fe12Mn1,5Mo ditunjukkan pada Tabel 2. 


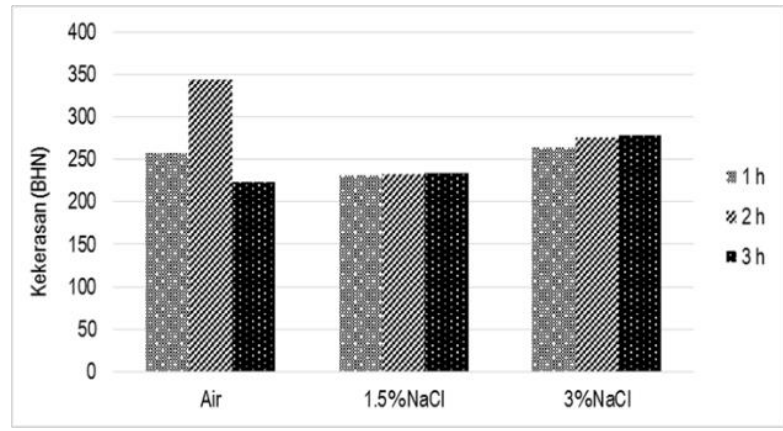

Gambar 4. Hasil uji keras paduan Fe12Mn1,5Mo

Tabel 2. Nilai kekerasan paduan Fe12Mn1,5Mo

\begin{tabular}{c|cc}
\hline Media pendingin & $\begin{array}{c}\text { Waktu } \\
\text { pelarutan }\end{array}$ & BHN \\
\hline \multirow{2}{*}{ Air } & 1 jam & 257 \\
\cline { 2 - 3 } & 2 jam & 344 \\
\cline { 2 - 3 } & 3 jam & 223 \\
\hline \multirow{2}{*}{$\begin{array}{c}\text { Larutan garam } \\
1.5 \%\end{array}$} & 1 jam & 232 \\
\cline { 2 - 3 } & 2 jam & 233 \\
\cline { 2 - 3 } & 3 jam & 234 \\
\hline \multirow{2}{*}{ Larutan garam 3\% } & 1 jam & 264 \\
\cline { 2 - 3 } & 2 jam & 276 \\
\cline { 2 - 3 } & 3 jam & 278 \\
\hline
\end{tabular}

Berdasarkan tabel di atas, secara umum nilai kekerasan yang dihasilkan pada penelitian ini tergolong rendah. Hal ini disebabkan karena terbentuknya formasi fasa austenit yang lunak pada matriks.

Namun, kekerasan tertinggi yang dapat dicapai melalui proses solution treatment pada penelitian ini adalah pada variasi holding time 2 jam dilanjutkan pendinginan air yang mencapai 344 BHN. Sebagaimana hasil uji EDS menggunakan JEOL JSM 6390a pada penelitian sebelumnya (Ridlo, et al. 2020) - tingginya nilai kekerasan ini disebabkan karena kehadiran jumlah unsur molibdenum pada struktur karbida yang lebih besar sebagaimana dapat dilihat pada Tabel 3 , sehingga memberikan pengaruh siginifikan terhadap kenaikan kekerasan. Menurut G. Razavi, et.al dalam penelitiannya menyatakan bahwa penambahan molibdenum pada baja akan mendorong terbentuknya karbida molibdenum $(\mathrm{Fe}, \mathrm{Mo})_{3} \mathrm{C}$ di batas butir (Razavi, Rizi and Zadeh 2013).
Tabel 3. Hasil uji EDS paduan Fe12Mn1.5Mo variasi waktu tahan 2 jam

\begin{tabular}{|c|c|c|c|}
\hline \multirow{2}{*}{ Unsur } & Air* & \begin{tabular}{c} 
Larutan \\
garam \\
\cline { 2 - 4 }
\end{tabular} & $\begin{array}{c}\text { Larutan } \\
\text { garam 3\% }\end{array}$ \\
\hline Fe & 36,09 & 51,83 & 50,21 \\
\hline Mn & 8,13 & 16,96 & 11,56 \\
\hline Mo & 48,48 & 27,93 & 34,16 \\
\hline
\end{tabular}

* (Ridlo, et al. 2020)

\section{Analisis Pengaruh Waktu Tahan Pada Variasi Media Pendingin Terhadap Nilai Impak}

Nilai impak pada spesimen setelah proses solution treatment ditunjukkan pada Gambar 5. Nilai impak cenderung meningkat seiring bertambahnya waktu tahan diikuti dengan pendinginan larutan garam 1,5\% dan 3\%. Hal ini mengindikasikan bahwa dengan semakin lama holding time, maka karbida memiliki waktu yang cukup untuk larut ke dalam matriks. Pada pendinginan spesimen menggunakan larutan garam 3\%, terjadi peningkatan energi impak cukup signifikan dari holding time 1 jam sebesar $48,8 \mathrm{~J} / \mathrm{cm}^{2}$ menjadi $71,8 \mathrm{~J} / \mathrm{cm}^{2}$ pada variasi holding time 2 jam dan terus meningkat dengan stabil menjadi $73,4 \mathrm{~J} / \mathrm{cm}^{2}$ pada variasi holding time 3 jam. Nilai impak yang rendah pada sampel pendinginan larutan garam 3\% dengan holding time 1 jam diduga karena proses pelarutan tidak berjalan dengan sempurna sehingga terbentuk presipitasi karbida (carbide precipitation) yang memberikan efek negatif terhadap ketangguhan (Nurjaman, et al. 2017) sebagaimana ditunjukkan pada Gambar 6. Hal ini diperkuat melalui gambar permukaan patahan spesimen impak masingmasing untuk variasi holding time 1 jam dan 3 jam dengan pendinginan larutan garam $3 \%$ yang ditunjukkan pada Gambar 7 (a dan b), berturutturut. Secara umum, bentuk patahan kedua spesimen berbentuk serabut yang mengindikasikan sebagai patahan ulet. 


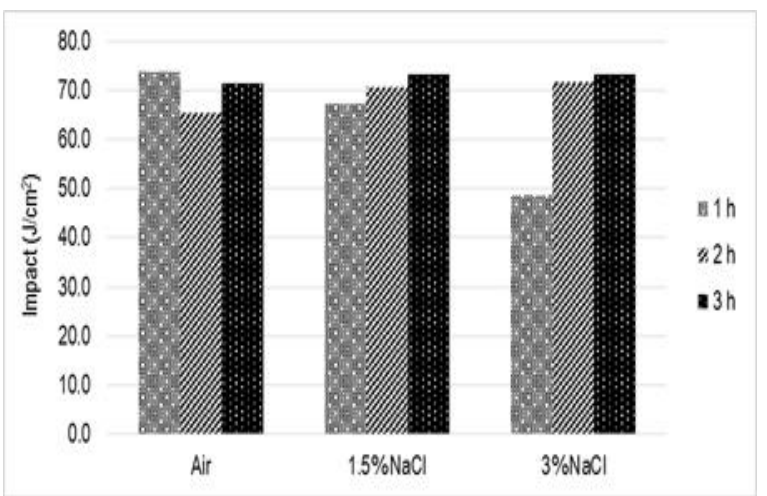

Gambar 5. Hasil uji impak paduan $\mathrm{Fe} 12 \mathrm{Mn} 1,5 \mathrm{Mo}$

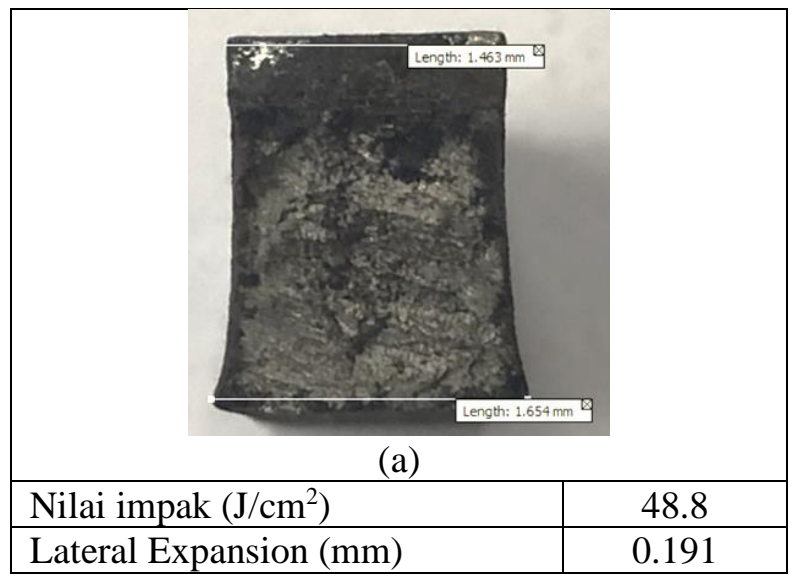

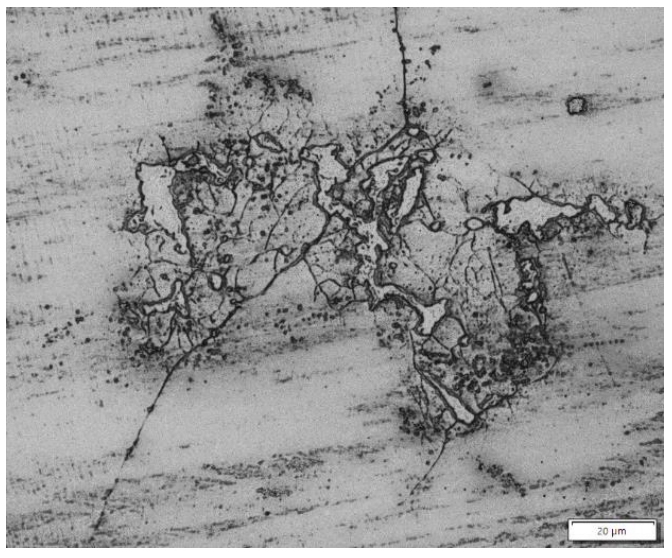

Gambar 6. Presipitasi Karbida paduan Fe12Mn1,5Mo

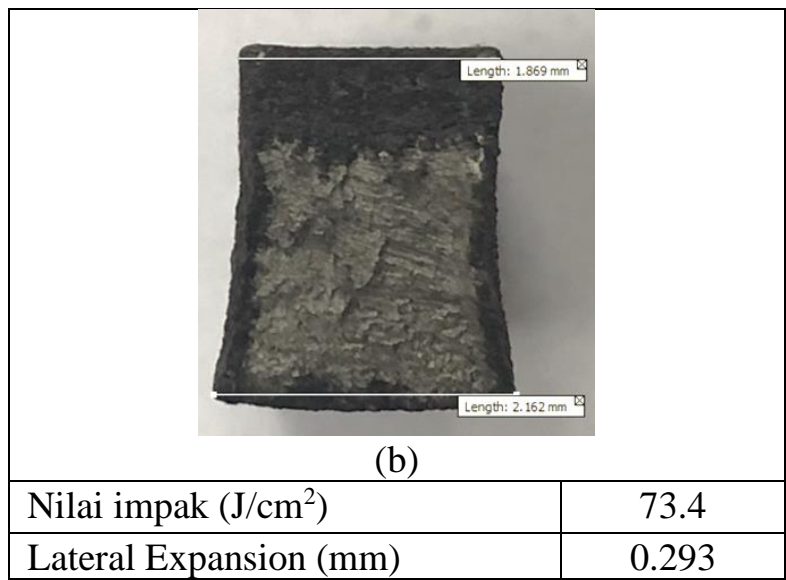

Gambar 7 Patahan spesimen impak paduan Fe12Mn1.5Mo pada variasi waktu tahan (a) 1 jam dan (b) 3 jam pendinginan larutan garam $3 \%$

Namun, untuk membuktikan bahwa kedua spesimen memiliki ketangguhan yang berbeda, maka dilakukan pengukuran nilai lateral expansion menggunakan software Digimizer. Dari hasil pengukuran, maka didapatkan kesimpulan bahwa nilai impak berbanding lurus dengan lateral expansion material. Spesimen dengan holding time 3 jam memiliki lateral expansion lebih besar, sehingga mengindikasikan bahwa spesimen tersebut memiliki ketangguhan lebih tinggi dibandingkan spesimen dengan variasi holding time 2 jam.

Sebaliknya, pendinginan di dalam air memberikan pengaruh yang berfluktuasi terhadap nilai penyerapan energi dengan bertambahnya holding time. Hal ini senada dengan nilai kekerasan yang berfluktuasi pada variasi pendinginan yang sama, namun dengan trend yang berlawanan, dimana dengan meningkatnya kekerasan maka nilai impak semakin rendah, begitu pula sebaliknya.

Apabila dilihat secara keseluruhan, maka nilai impak dari baja paduan Fe12Mn1.5Mo pada semua variasi memiliki nilai yang tidak begitu berbeda. S. Hosseini, et.al (Hosseini and Limooei 2011) dalam penelitiannya menjelaskan bahwa penggunaan larutan garam sebagai media pendingin mampu meningkatkan laju pendinginan dan menghalangi terbentuknya karbida pada batas butir sehingga meningkatkan ketangguhan. Bagaimanapun juga, energi impak optimum mampu dicapai pada variasi holding time 1 jam dengan pendinginan di dalam air yaitu sebesar $73,7 \mathrm{~J} / \mathrm{cm}^{2}$. 


\section{KESIMPULAN}

Melalui penelitian proses solution treatment menggunakan paduan Fe12Mn1.5Mo ini, dapat disimpulkan bahwa komposisi paduan baja yang dibuat melalui proses pengecoran konvensional dilanjutkan dengan proses solution treatment dengan pemanasan bertahap ini menghasilkan struktur mikro berupa fasa austenit yang dominan sebagai matriks dengan kehadiran karbida tak larut (undissolved carbide) pada batas butir dan di dalam butir. Formasi austenit yang lunak pada matriks menyebabkan nilai kekerasan pada penelitian ini tergolong rendah dengan rentang sebesar 223 - 344 BHN. Pada penelitian ini, nilai kekerasan dan impak menunjukkan semakin meningkat seiring dengan bertambahnya holding time dilanjutkan proses pendinginan menggunakan larutan garam $1.5 \%$ dan $3 \%$. Sementara itu, baik nilai kekerasan maupun ketangguhan spesimen cenderung berfluktuasi dengan semakin meningkatnya waktu tahan pada pendinginan di dalam air. Nilai kekerasan tertinggi sebesar 344 BHN dicapai pada variasi holding time 2 jam diikuti dengan pendinginan air. Hal ini disebabkan karena jumlah unsur molibdenum pada karbida yang lebih besar berdasarkan pengukuran EDS. Sementara itu, nilai impak optimum sebesar $73.7 \mathrm{~J} / \mathrm{cm}^{2}$ dicapai pada variasi holding time 1 jam diikuti dengan pendinginan air. Sedangkan, nilai impak paling rendah sebesar $48.8 \mathrm{~J} / \mathrm{cm}^{2}$ terjadi pada variasi holding time 1 jam dilanjutkan dengan pendinginan larutan garam 3\%. Proses solution treatment yang berlangsung kurang sempurna berakibat kepada menurunnya ketangguhan karena terbentuknya presipitasi karbida.

\section{UCAPAN TERIMA KASIH}

Penulis menuliskan ucapan terima kasih kepada Laboratorium Preparasi Mekanik dan Metalografi, Laboratorium Uji Mekanik serta Laboratorium SEM-EDS Pusat Penelitian Metalurgi dan Material LIPI yang mensupport penuh pelaksanaan penelitian ini dan seluruh tim peneliti dan teknisi yang turut serta berkontribusi mulai persiapan, pelaksanaan hingga penulisan artikel ilmiah ini.

\section{DAFTAR PUSTAKA}

Agunsoye, Johnson Olumuyiwa, and S I Talabi. 2015. "Wear characteristics of heat- treated Hadfield austenitic manganese steel for engineering application." Advances in Production Engineering \& Management 10: 97-107. doi:http://dx.doi.org/10.14743/apem2015 .2.195.

Bahfie, F, Z Aleiya, A Milandia, and F Nurjaman . 2020. "Studi pengaruh kadar mangan dan temperatur austenisasi terhadap struktur mikro dan sifat mekanik baja mangan." Dinamika Teknik Mesin 10: 69-75.

Banerjee, M.K. 2017. "Comprehensive Materials Finishing." In Manganese Steel-an Overview, 2-4. Science Direct. https://www.sciencedirect.com/topics/ma terials-science/manganese-steel.

Enginsoy, Halil Murat, Emin Bayraktar, and Ali Kursun. 2018. "A Comprehensive Study on the Deformation Behavior of Hadfield Steel Sheets Subjected to the Drop Weight Test: Experimental Study and Finite Element Modeling." metals 08: 1-18. doi:10.3390/met8090734.

Ham, Youn Soo, Jeong Tae Kim, Si Young Kwak, Jeong Kil Choi, and Woo Young Yoon. 2010. "Critical cooling rate on carbide precipitation during quenchingof austenitic manganese steel." China Foundry 178-182.

Hidayat, Ery, and Beny Bandanadjaja. 2018. "Peningkatan Nilai Impak Baja Hadfield Mn 12 Melalui Proses Perlakuan Panas Homogenisasi Bertahap." Jurnal Energi dan Teknologi Manufaktur 01: 09-14.

Hosseini, Shabnam, and Mohammad Bagher Limooei. 2011. "Optimization of Heat Treatment to Obtain Desired Mechanical Properties of High Carbon Hadfield Steels." World Applied Sciences Journal 15: 1421-1424.

Kumar, Arvind. 2019. "Reducing the Time of Heat Treatment Cycle of the Manganese Steel." International Journal of Innovative Technology and Exploring Engineering (IJITEE) 08: 89-91. doi:DOI: 10.35940/ijitee.L1027.10812S19.

Nurjaman, F, F Bahfie, W Astuti, and A Shofi. 2017. "The effect of solid solution treatment on the hardness and microstructure of $0.6 \% \mathrm{wt} \mathrm{C}-10.8 \% \mathrm{wt}$ 
Mn-1.44\%wt $\mathrm{Cr}$ austenitic manganese steel." 2nd International Symposium on Frontier of Applied Physics (ISFAP 2016). doi:doi:10.1088/17426596/817/1/012066.

Okamoto, H. 1992. "The Materials Information Society." In ASM Handbook Vol.3 Alloy Phase Diagram, by ASM International.

Okechukwu, Chijioke, Olurotimi Akintunde Dahunsi, Peter Kayode Oke, Isiaka Oluwole Oladele, and Mohammed Dauda. 2017. "Prominence of Hadfield Steel in Mining and Minerals Industries: A Review." International Journal of Engineering Technologies-IJET 03: 8390.

Pratomo, Sri Bimo, Husein Taufiq, Mahaputra, and Winda Sri Jaman. 2016. "Penelitian dan Pengembangan material Jaw Plate yang Terbuat Dari Baja Mangan untuk Subtitusi Impor." Jurnal Riset Industri 10: 98-106.

Razavi, Gholam Reza, Mohsen Saboktakin Rizi, and Hossein Monajati Zadeh. 2013. "Effect Of A Mo Addition On The Properties Of High-Mn Steel." Materials and technology 611-614.

Ridlo, Faried Miftahur, Permana Andi Paristiawan, Dedi Pria Utama, and Fatayalkadri Citrawati. 2020. "Study on the effect of solution treatment soaking time on structure development of modified FeNiMn steels." Proceedings of the 3rd International Seminar on Metallurgy and Materials (ISMM2019). Tangerang Selatan: AIP Publishing. 060008-1 - 060008-9. doi:https://doi.org/10.1063/5.0001961.

Tecza, G, and S Sobula. 2014. "Effect of Heat Treatment on Change Microstructure of Cast High-manganese Hadfield Steel with Elevated Chromium Content." Foundry Engineering 14: 67-70.

Widyanto, Bambang, and Achmad Sambas. 2007. "Pengaruh Waktu Austenitisasi Pada Proses Pelarutan Karbida Baja Mangan Austenitik." Jurnal Teknik Mesin 22: 1-8. Winarto, Eko Wismo, Suryo Darmo, Nugroho Santoso, and Lilik Dwi Setyana. 2019. "The Improvement of Impact on Manganes Steel for Bucket Tooth
Product." International Conference on Technology for Sustainable Development $2018 . \quad 78-83$. doi:DOI 10.18502/kss.v3i23.5138. 